\title{
ISTARSKO HRVATSKO SVEĆENSTVO I DIPLOMATSKO- -POLITIČKA BORBA ZA SJEDINJENJE ISTRE S HRVATSKOM (1945.-1954.)
}

Stipan TROGRLIĆ

Institut društvenih znanosti Ivo Pilar - Područni centar Pula, Pula

UDK: 322(497.5-3lstra)"1945/1954":327.82

Izvorni znanstveni rad

Primljeno: 2. 2. 2011.

$U$ radu se, na temeliu arhivskoga gradiva, tiska i literature, analizira uloga istarskoga hrvatskog svećenstva u diplomatsko-političkoj borbi za sjedinjenje Istre s maticom Hrvatskom, u prvom desetljeću te borbe nakon završetka Drugoga svjetskog rata. U prvoi fazi (1945.-1947.) hrvatsko se svećenstvo, predvođeno karizmatičnim Božom

Milanovićem, na poziv nove "narodne vlasti" uključuje aktivno u tu borbu: ulazi u pregovaračke timove, piše elaborate za političare, izručuje Spomenicu Savezničkoj komisiii u Pazinu, drži govore na političkim mitinzima. U drugoj, dužoj, fazi (1947.-1954.) dolazi do

(samo)marginalizacije hrvatskoga svećenstva u diplomatsko-političkim zbivanjima oko rješavanja spornoga područja između Jugoslavije i Italije, poznatog kao Slobodni Teritorii Trsta. Bila je to posliedica, s jedne strane, uvjerenja državnog aparata da joj više nije potrebna pomoć svećenstva $a, s$ druge strane, samo je svećenstvo smatralo da je povijesnu ulogu odigralo u prethodnoj fazi te da se "učrršćena" država sama može nositi s novim izazovima diplomatsko-političke borbe za "ostatak" Istre. Nastupi svećenika sada su svedeni na pisanje spomenica i izjava u kojima ustaju protiv talijanskih iredentističkih zahtjeva za Istrom i pružaju podršku jugoslavenskoj vlasti u obrani zapadnih granica.

Ključne riječi: Istra, diplomatska borba, sjedinjenje, hrvatsko svećenstvo, Božo Milanović

Stipan Trogrlić, Institut društvenih znanosti Ivo Pilar Područni centar Pula, Leharova 1, 52100 Pula, Hrvatska. E-mail: Stipan.Trogrlic@pilar.hr 
Izjave vodstva Narodnooslobodilačkoga pokreta (NOP-a) u Istri na početku 1944. o tome kako će se sudbina Istre i čitave Julijske Venecije ${ }^{1}$ rješavati na bojnom polju, a ne za zelenim stolom, ${ }^{2}$ pokazat će se djelomično nerealnima. Naime, odmah nakon završetka rata bilo je jasno da će se pitanje toga graničnog područja ipak rješavati za pregovaračkim stolom, ali isto tako bilo je jasno da je prisutnost vojske na tom području odredila bolje pregovaračke pozicije. Jugoslavensko državno-partijsko vodstvo, svjesno da bi mu u političko-diplomatskoj borbi za pridruženje Julijske Venecije Jugoslaviji mogla biti od koristi pomoć pojedinih uglednih istarskih svećenika, u prvom redu Bože Milanovića, dali su signal vodstvu NOP-a u Istri da pokuša stupiti u kontakt s Milanovićem i pridobiti ga za suradnju. Na ranija upozorenja nekih svećenika i barbanskoga narodnjaka Ivana Kolića da jedino pozitivno rješenje "slučaja" svećenika Bože Milanovića i Zvonimira Brumnića (koji su tada zbog vlastite sigurnosti živjeli u Trstu, jer ih je vodstvo NOP-a prozivalo kao najgore narodne neprijatelje) može otvoriti put suradnje s istarskim klerom, vodstvo Oblasnoga NOO-a za Istru do tada se jednostavno na te izjave nije obaziralo (Grah, 1997., 57-59).

Nakon uzaludnih pokušaja na početku 1945. da se Milanovića dovede $\mathrm{u}$ Istru, $\mathrm{u}$ Istri nije bilo javne manifestacije na kojoj nije bio prozivan, skupa s Brumnićem, kao izdajica i narodni neprijatelj. Ipak, pod pritiskom događaja, kao što je Beogradski i Devinski sporazum, ${ }^{3}$ a u želji da pokaže svoj legitimitet pred međunarodnom i domaćom javnosti, nova se vlast odlučila za pregovore s dojučerašnjim najprozivanijim neprijateljem. I ono što je još prije mjesec dana izgledalo nemoguće ipak se dogodilo. U Trstu je 16. srpnja 1945. došlo do sastanka predstavnika NOP-a Dušana Diminića i Ivana Motike s Božom Milanovićem, na kojem su precizirani uvjeti međusobne suradnje. Predstavnici "nove narodne vlasti" dobili su obećanje da će istarsko svećenstvo, u posebnoj izjavi, izraziti podršku novoj vlasti, dok će NOP osigurati Crkvi u Istri takve mogućnosti djelovanja kakve su tada bile nezamislive u ostalim dijelovima Jugoslavije. ${ }^{4}$

Na sastanku održanom 18. srpnja. 1945. u Pazinu Ivan Motika je obavijestio 30-ak nazočnih svećenika o sporazumu između članova Oblasnoga NOO-a za Istru i Milanovića, što su, prema Milanovićevom svjedočanstvu, svećenici prihvatili sa zadovoljstvom. Jedinstveni narodnooslobodilački front (JNOF) za Istru sazvao je za 31. srpnja 1945. istarske svećenike na sastanak, na kojem su se trebali odrediti daljnji oblici suradnje. Iako su oba istarska biskupa bila protiv održavanja sastanka, Santin je čak preporučio Milanoviću da se ne potpisuje nikakva izjava o priključenju Istre Jugoslaviji, na sastanku održanom 
DRUŠ. ISTRAŽ. ZAGREB GOD. 21 (2012), BR. 2 (116)

STR. $485-504$

TROGRLIĆ, S.: ISTARSKO HRVATSKO..
31. srpnja 1945. u franjevačkom samostanu u Pazinu, 44 svećenika su potpisala izjavu u kojoj se traži da "(...) mora biti Istra iz etničkih, geografskih i ekonomskih razloga priključena Demokratskoj Federativnoj Jugoslaviji" (Milanović, 1996., 167-173). Suočeni sa zabranom svojih biskupa, istarski su svećenici sa sastanka u Karojbi 29. srpnja uputili molbu JNOF-u za Istru da ODGODI (istaknuto $u$ originalu, op. aut.) sastanak sazvan za 31. srpnja. Iz pisma doznajemo da je na sastanku predstavnika JNOF-a i svećenika 18. srpnja dogovoreno da će o sastanku sazvanom za 31 . srpnja biti obaviješteni biskupi. ${ }^{5}$ Pritisnuti s jedne strane zabranama svojih biskupa, a s druge strane inzistiranjem vlasti da se sastanak svakako održi, svećenici su posegnuli za salomonskim rješenjem. Odlučili su da će sastanak imati privatni karakter, tj. svećenici će biti pozvani na sastanak kao privatne osobe (građani), a ne kao pripadnici svećeničkoga staleža (Milanović, 1996., 171-172).

\section{AKTIVNO UKLJUČIVANJE SVEĆENIKA U DIPLOMATSKO-POLITIČKU BORBU 1945.-1947.}

Memorandum hrvatskih i slovenskih svećenika Savezničkoj vojnoj upravi u Trstu, upućen 20. srpnja 1945., na sintetiziran je način objasnio etničke, povijesne, gospodarske i kulturne razloge zbog kojih svećenici traže pridruženje Julijske Venecije Jugoslaviji. Već u Memorandumu svećenici ističu da, unatoč brzom razočaranju novom (partizanskom) vlašću, "žele i hoće priključenje Jugoslaviji, ali sigurno ne komunističkoj, nego istinski demokratskoj i narodnoj".6 Svećenici kao članovi ili simpatizeri Kršćansko-socijalne stranke vjerovali su u uspostavu demokratskih standarda u Jugoslaviji, u kojima bi se kršćanski socijalisti pojavili kao partner Komunističkoj partiji. I sam se Milanović, sve do završetka rata, nadao uspostavi parlamentarne demokracije $\mathrm{u}$ Jugoslaviji. Zato se spremao obnoviti Narodno-kršćansku stranku, koja bi, u danom trenutku, uz pomoć saveznika, sudjelovala u preuzimanju vlasti u Istri (Milanović, 1996., 115.; Grah, 2004., 19). Međutim, kad se uvjerio da nova (komunistička) vlast ne pomišlja na dijeljenje vlasti ni s kim, odustao je od svoje nakane, prihvatio je tu vlast i počeo surađivati s njome. Tom njegovom suradničkom odnosu priključio se najveći dio istarskoga hrvatskog svećenstva. Kad već nije bilo moguće uspostaviti političko-stranačke partnerske odnose, istarsko svećenstvo nastojalo se izboriti za poziciju čimbenika o čijim će zahtjevima partijsko-državni vrh morati voditi računa.

Na temelju odluka konferencije u Postdamu (17. svibnja 1945.), u Londonu je od 11. rujna do 2. listopada 1945. sazvana konferencija na kojoj su ministri vanjskih poslova SAD-a, SSSR-a, Velike Britanije, Francuske i Kine raspravljali o razgraničenju između Italije i Jugoslavije. U radu konferencije sudje- 
DRUŠ. ISTRAŽ. ZAGREB GOD. 21 (2012) BR. 2 (116)

STR. 485-504

TROGRLIĆ, S.: ISTARSKO HRVATSKO.. lovali su i ministri vanjskih poslova Jugoslavije i Italije: Eduard Kardelj i Alcide De Gasperi. U svojem dokazivanju opravdanosti zahtjeva za pripajanje Julijske krajine Jugoslaviji Kardelj se služio elaboratom B. Milanovića "Zašto mora Julijska krajina pripasti Jugoslaviji?", kao i drugim člancima ("Wilsonova linija značila bi za Jugoslaviju gubitak Istre", "Zašto bi plebiscit u Istri bio prevelika krivica za Hrvate u Istri"? "Talijanstvo Trsta"), koje je Milanović napisao na poziv predsjednika vlade NR Hrvatske, Vladimira Bakarića (Milanović, 1976., 127-128).

Polazište Milanovićeva elaborata bio je Memorandum hrvatskih i slovenskih svećenika Savezničkoj komandi od 20. srpnja 1945. Stavljanje u prvi plan "etnoloških" (etničkih) razloga trebalo je pokazati ne samo brojčanu prevlast "slavenskog" elementa u Julijskoj krajini nego još više njegovu kompaktnost u naseljenosti toga područja. "Talijani sežu kompaktno samo do Soče, dotično do Monfalconea (Tržiča), a odatle dalje počinje slavensko pučanstvo. Talijani su dakle sa svojim gradićima na tuđem teritoriju. To vrijedi ne samo za Goricu, koja je po svom pučanstvu mješovita, i za Trst, u kojemu su već sama predgrađa slovenska, nego također i za zapadnu istarsku obalu, gdje je također među talijanskim gradićima nastanjeno hrvatsko pučanstvo".

Dolazak 37-člane Savezničke komisije (engleska je delegacija brojila 7, američka 8 , ruska 13 i francuska 9 članova) u ožujku 1946. pratile su razne javne manifestacije, u kojima su obje strane, jugoslavenska i talijanska, dokazivale opravdanost svojih teritorijalnih zahtjeva prema području nekadašnje Julijske Venecije. Veću diplomatsku težinu od svih manifestacija imala je Spomenica "Zbora svećenika sv. Pavla" sa statistikom o nacionalnoj strukturi župa u Porečko-pulskoj, Tršćansko-koparskoj i Riječkoj biskupiji,7 koju su komisiji predali članovi "Zbora" Božo Milanović, Tomo Banko i Leopold Jurca prilikom audijencije u zgradi pazinskoga sjemeništa 19. ožujka 1946. Kad je Saveznička komisija 23. ožujka 1946. došla u Pulu, biskup Radossi smatrao je svojom dužnošću posjetiti neke članove Komisije i upoznati ih s mišljenjem svojega klera, "poznavajući njegovo stvarno mišljenje". Nažalost, zapisnik s toga sastanka nije sačuvan ili jednostavno nije ni postojao, pa se o Radossijevu referiranju mišljenja klera njegove biskupije može samo nagađati. Međutim, nije teško pretpostaviti da je stavove iznesene u "Spomenici" ili relativizirao ili negirao. ${ }^{8}$

Spomenica je naglasak stavila na povijesne nepravde koje su Hrvati i Slovenci doživjeli u vrijeme talijanskoga vladanja Julijskom Venecijom te na opravdanost zahtjeva za njezinim pridruženjem Jugoslaviji, na temelju etničkoga sastava stanovništva. Taj zahtjev sad je dobivao na težini jer su iza njega stajali ne samo narod i nova vlast nego i katoličko svećenstvo. 
DRUŠ. ISTRAŽ. ZAGREB GOD. 21 (2012), BR. 2 (116)

STR. $485-504$

TROGRLIĆ, S.: ISTARSKO HRVATSKO..
U tom smislu ona ne donosi ništa nova što već ranije, u raznim svećeničkim iskazima, nije bilo rečeno. Za novu vlast veliki plus u očima međunarodne komisije bio je onaj dio Spomenice koji govori da je nova vlast osigurala vjerske slobode i Hrvatima i Talijanima. ${ }^{9}$ Time su dovedeni u pitanje navodi istarskih biskupa o ugrožavanju vjerske slobode od strane partizanske vlasti, ali i upozorenje "Zbora" Oblasnom NOO-u, koji se od 15. veljače 1946. nalazio u Labinu, o kršenju vjerskih sloboda u Istri. Izjava o (ne)postojećim vjerskim slobodama može se razumjeti u kontekstu trenutka u kojem je, u očima svjetske javnosti, trebalo pokazati demokratsko lice nove vlasti, bez obzira na to koliko je to zaista bila istina.

Teoretsko uporište svojoj podršci novoj (revolucionarnoj) vlasti hrvatsko je svećenstvo našlo u učenju Tome Akvinskog, koji je dopuštao "pobunu" protiv raznih oblika tiranije, osim ako bi takva pobuna donijela više štete od same tiranije. ${ }^{10} \mathrm{U}$ jednom članku u "Gore srca" između redaka može se pročitati kako je jugoslavenska revolucija, iako je donijela prolijevanje krvi, ipak manje zlo od talijanske, fašističke, diktature u Istri. ${ }^{11}$ Drugi nepotpisani članak, čiji je autor, kao i onoga prethodnog, najvjerojatnije bio Milanović, nastoji objasniti kršćansko shvaćanje o tome da svaka vlast dolazi od Boga. Na općoj, načelnoj, razini Bog, kao vrhovni gospodar, dopušta određeni oblik vlasti i u tom smislu svaka je vlast od Boga, međutim Bog ne određuje izravno ni na bilo koji način ovaj ili onaj oblik vlasti, to je stvar povijesnih prilika i slobodne ljudske volje. 12

Stav hrvatskoga i slovenskoga svećenstva u Istri prema političkoj sudbini Istre nakon rata najjasnije je izrazio Leopold Jurca, rektor sjemeništa u Pazinu, $\mathrm{u}$ predavanju pod naslovom "Noi Slavi siamo fatti cosi - Mi Slaveni smo takvi", koje je na poziv biskupa Santina održao talijanskim svećenicima $u$ Trstu 2. srpnja 1946. godine. Evo bitnoga dijela toga predavanja: "Dobro je poznato da mnogi loše tumače i kritiziraju naš stav i naš rad s obzirom na buduće granice između Italije i Jugoslavije, kao da mi slavenski svećenici ne bismo vodili nikakvog računa o ateističkoj opasnosti kojoj idemo u susret želeći ostati u Jugoslaviji. Mi smo i te kakao svjesni te opasnosti, no u ovom povijesnom trenutku imamo mogućnosti birati nacionalnu slobodu, iako pomiješanu s antivjerskom propagandom, ili ostati u stranoj državi i neprijateljskoj kakvom se pokazala sve do sada u nacionalnim odnosima s nakanom potpune denacionalizacije našeg naroda. I potom, ne može se reći da se i Italija ne može jednog dana, tijekom vremena, naći u istoj ili sličnoj situaciji kao što je naša u odnosu na vjeru".13

U pripremama za Parišku mirovnu konferenciju, koja je trebala riješiti sporna jugoslavensko-talijanska granična pitanja, u radu jugoslavenske delegacije od početka svibnja do 
DRUŠ. ISTRAŽ. ZAGREB GOD. 21 (2012) BR. 2 (116),

STR. $485-504$

TROGRLIĆ, S.: ISTARSKO HRVATSKO.. kraja lipnja 1946. sudjelovali su svećenici Tršćansko-koparske biskupije: Hrvat Božo Milanović i Slovenac Anton Piščanec. Kao katolički svećenici, imali su zadatak uvjeriti francuske katoličke krugove $\mathrm{u}$ opravdanost jugoslavenskih zahtjeva. Već trećega dana boravka u Parizu dogodio se susret B. Milanovića s katoličkim novinarom Walterom Eberhardom, koji se nije mogao načuditi kako to da se Milanović kao katolički svećenik radije priklonio komunističkoj Jugoslaviji nego katoličkoj Italiji. Na Eberhardovo čuđenje, Milanović je odgovorio poznatom, pomalo antologijskom, rečenicom: "Državne granice određuju se za stoljeća, dok se režimi mijenjaju, a pod Italijom je u opasnosti život našeg naroda." (Milanović, 1996., 294). Bez sumnje Milanovićevo lobiranje protiv plebiscita u Istri, zbog posljedica 25-godišnje sustavne politike talijanizacije, utjecalo je na zapadne saveznike da odustanu od prijedloga da se pitanje pripadnost Istre riješi plebiscitom. ${ }^{14}$ Međutim, jugoslavenska je vlast, ponesena pobjedom $u$ ratu, vjerovala da bi se stanovništvo Istre na referendumu plebiscitarno opredijelilo za Jugoslaviju, pa je u određenom trenutku zastupala plebiscit kao najprihvatljiviji način rješavanja graničnih sporova s Italijom. Nikola Moscatello, jugoslavenski otpravnik poslova pri Svetoj Stolici, otputovao je u Beograd kako bi uvjerio Tita da ne podrži održavanje referenduma u Julijskoj krajini. Na Moscatellovu intervenciju utjecale su i informacije o istarskim prilikama koje mu je pružio mladi svećenik porečko-pulske biskupije Ivan Pavić, postdiplomac kanonskoga prava na papinskom sveučilištu Gregoriani (Grah, 1992., 109).

Lobiranje ove dvojice svećenika, posebno Milanovića, u francuskim i belgijskim katoličkim krugovima za rješenje Julijskoga pitanja u korist Jugoslavije, posebno prijam kod pariškog kardinala Souharda nakon kojeg su se počele širiti vijesti da i kardinal smatra jugoslavenske zahtjeve opravdanima, ponukale su obojicu istarskih biskupa da se izravno obrate kardinalu Souhardu (Riccardi, 1989., 62-65).

Vijeće ministara (SAD, SSSR, V. Britanija i Francuska) na četvrtoj konferenciji u Parizu 1. srpnja 1946. donijelo je sljedeće odluke: Jugoslaviji će pripasti područje istočno od francuske crte razgraničenja, tj. čitava Istra, osim Bujštine i Koparštine. Na području od rijeke Mirne do Devina s Trstom formirat će se Slobodni Teritorij Trsta (STT) pod nadzorom Vijeća sigurnosti UN-a. STT bit će podijeljen na dvije zone, zonu "A" (Trst s okolicom, od Devina do Milja), pod savezničkom upravom, i zonu "B" (teritorij od Milja do Novigrada), pod jugoslavenskom upravom. Italiji je trebao pripasti sjeverni dio Kanalske doline, Gorica i Monfalcone. Nakon duge i mučne diplomatske borbe, iako nezadovoljna ovim odredbama, Italija je sa silama pobjednicama, među kojima je bila i Jugoslavija, u 
DRUŠ. ISTRAŽ. ZAGREB GOD. 21 (2012), BR. 2 (116)

STR. $485-504$

TROGRLIĆ, S.: ISTARSKO HRVATSKO..
Parizu 10. veljače 1947. potpisala mirovni ugovor, koji je sadržavao rješenje graničnoga pitanja u skladu s odlukom Vijeća ministara od 1. srpnja 1946. I kod talijanske i kod jugoslavenske delegacije bila je prisutna svijest da je sporazum potpisan pod pritiskom međunarodne zajednice i da se radi o privremenom rješenju za STT, dok je ostatak definitivno riješen. Obostrano prisutne frustracije i uvjerenje da $u$ konačnom rješenju treba izboriti pravednije rješenje bile su izvor kasnijih sporova koji su dovodili do napetosti i mahanja oružjem ( $\mathrm{Hr}-$ ženjak, 1952., 61).

Unatoč određenom nezadovoljstvu zbog toga što se nije ostvario maksimalan plan, tj. pridruženje čitave Julijske Venecije Jugoslaviji, Pariški mirovni ugovor dočekan je u jugoslavenskim krugovima kao diplomatski uspjeh nove vlasti. To potvrđuju i brzojavi koje je "Zbor svećenika sv. Pavla za Istru" 25. veljače 1947. uputio predsjedniku jugoslavenske vlade, maršalu Titu, predsjedniku hrvatske vlade, Vladimiru Bakariću, i ministru u hrvatskoj vladi, svećeniku Svetozaru Ritigu. Dok se u brzojavu Titu ističe zahvalnost njemu i pokretu "za oslobođenje i vjernost državi", 15 u brzojavu Bakariću izražava se radost istarskoga svećenstva zbog priključenja Istre "hrvatskoj domovini". 16

Ratifikacija Pariškoga mirovnog ugovora od strane pojedinih država potpisnica 15. rujna 1947. te ukaz Prezidija Narodne skupštine FNRJ od 16. rujna 1947., kojim Ustav i zakoni FNRJ vrijede za novopriključene krajeve, označili su kraj jedne etape u diplomatskoj borbi za jugoslavensku zapadnu granicu. B. Milanović, aktivni sudionik svih poslijeratnih diplomatsko-političkih sporova i borbi, ovako je doživio kraj tih borbi: "Kao kad lađa nakon dugog putovanja i mnogih oluja uđe u svoju luku, tako se je i hrvatski narod $\mathrm{u}$ Istri nakon više nego tisućgodišnje podređenosti tuđincima napokon sjedinio sa svojom narodnom državom Hrvatskom u Jugoslaviji. Stoljetna je borba između hrvatstva i talijanstva u Istri svršila konačno nama u prilog. Pravda je pobijedila nepravde. Na Jadranskom moru napokon su uspostavljeni 'Božji međaši'. Svoje narodno sjedinjenje bio bi dočekao i proslavio naš narod $u$ Istri s nezapamćenim veseljem da nije bio razočaran osjećajući kako mu komunizam sve više ugrožava duhovna i materijalna dobra, osobna prava, slobodu i - narodni ponos. Ali uviđavniji su se ljudi i u toj novoj nevolji pouzdavali u pravdu te su shvaćali da privremeno zlo ne smije zasjeniti trajno dobro." (Milanović, 1996., 313).

Ako su za Milanovića nove granice bili "Božji međaši", tako ih je nazvao prema istoimenom romanu Ivana Pregelja (Bratulić, 2005., 624), za talijanske su duhovnike, iako to nigdje nisu eksplicite izjavili, bili "vražji međaši". Tako je biskup San- 
DRUŠ. ISTRAŽ. ZAGREB GOD. 21 (2012) BR. 2 (116)

STR. $485-504$

TROGRLIĆ, S.: ISTARSKO HRVATSKO.. tin mjesec dana prije potpisivanja Mirovnog ugovora u Parizu izneseni prijedlog, po kojem bi čitava zapadna obala Istre i grad Pula pripali Jugoslaviji, nazvao "užasnom stvari" i "velikom nepravdom" (Galimberti, 1996., 350). Isto mišljenje zastupali su i talijanski svećenici. No neki su od njih, svjesni da je podjela Istre prema Beogradskom sporazumu privremena, strahovali da će buduća rješenja za Italiju biti još gora (Istranin, 1965., 114). Drugi su pak bili razočarani činjenicom da su njihovi sunarodnjaci, posebno oni iz Pule, počeli odlaziti u Italiju. Tada se na ulicama umjesto talijanskog čuo hrvatski, srpski ili slovenski jezik (Gomiero, 1995., 30).

Iako su talijanski i jugoslavenski parlamenti ratificirali $\mathrm{Pa}$ riški mirovni ugovor, kod obiju strana on je stvarao frustracije jer su ga doživljavale kao odstupanje od svojih prvotnih zahtjeva. To više što su na njega pristali pod pritiskom vodećih sila, a samo zato da bi se očuvao mir na granici istočne i zapadne interesne sfere, tj. zemalja zapadne demokracije i istočnoga socrealizma. U tom kontekstu moguće je razumjeti Tripartitnu deklaraciju od 20. ožujka 1948., u kojoj SAD, Engleska i Francuska zahtijevaju da se Italiji vrati cijeli teritorij STT-a. Objašnjenje za donošenje Deklaracije tri spomenute zemlje našle su u činjenici da se talijanska i jugoslavenska strana nikako nisu mogle dogovoriti oko osobe guvernera, što je bio preduvjet funkcioniranja STT-a kao svojevrsne tamponske državice (De Castro, 1981.a, 721-723). Osim toga, "vraćanje Slobodnog Teritorija Trsta pod talijanski suverenitet najbolji je način da se izađe $u$ susret demokratskim težnjama naroda $i$ da se omogući uspostavljanje mira i stabilnosti u zoni" (Petacco, 2003., 203).

Tripartitna deklaracija je, s jedne strane, imala zadatak pomoći De Gasperiju pred izbore, koji su se trebali održati 18. travnja 1948., a s druge strane trebala je pomaknuti željeznu zavjesu od predgrađa Trsta prema rijeci Mirni. Reakcije na Tripartitnu deklaraciju bile su predvidive: talijanska ju je vlada objeručke prihvatila, dok ju je jugoslavenska vlada, podržana od sovjetske, odlučno odbacila. Hrvatski crkveni krugovi u Istri nisu se oglasili očekivanom osudom Deklaracije, kao što ni talijanski crkveni krugovi, u prvom redu biskup Santin, nisu podržali Deklaraciju. ${ }^{17} \mathrm{O}$ razlozima ovakva pomalo neočekivanog stava crkvenih krugova može se samo nagađati. Teško je vjerovati da je iz Vatikana stiglo upozorenje crkvenim krugovima da se ne uključuju u vruću diplomatsko-političku borbu oko Trsta i Istre, jer je i hrvatsko, slovensko i talijansko svećenstvo u toj borbi stalno prisutno. Isto tako nije vjerojatno da bi jedan tako krupan događaj kao što je Tripartitna deklaracija ostao nezapažen. Bližom istini čini nam se pretpostavka da se na Deklaraciju iz crkvenih krugova nije reagiralo 
jer se očekivalo da će državne institucije pravodobno reagirati - bilo da se dokaže potreba njezina provođenja, bilo da se pokaže njezina neutemeljenost i neprovedivost.

\section{MARGINALIZACIJA SVEĆENSTVA U DIPLOMATSKOJ BORBI}

Raskid sa SSSR-om, nakon Rezolucije Informbiroa 26. lipnja 1948., otvarao je perspektivu opće demokratizacije jugoslavenskoga društva, unutar koje se realnom činila mogućnost širenja vjerskih sloboda. Međutim, na unutrašnjem planu nije došlo do nekih znatnijih pomaka - KPJ je nastojala pošto-poto i dalje sačuvati monopol u svim sferama društvenoga života. Rim i Vatikan i dalje su apostrofirani kao glavni neprijatelji jugoslavenskoga državnog i društvenog uređenja. Jasni signali iz tršćanske kurije o STT-u kao talijanskom prostoru još su više stvarali negativne naboje prema Katoličkoj crkvi u cjelini, što je onda rezultiralo nepovjerenjem i prema mjesnoj Crkvi. Sudski proces kardinalu Stepincu, zabrana svećeničkih udruženja, oduzimanje prava javnosti vjerskim školama, sudski procesi i, kao kruna svemu, prekid diplomatskih odnosa s Vatikanom utjecali su na odnos Crkve i države i na Istarskom poluotoku.

Od 1948. do 1952. talijanski kler, a posebno biskup Santin, nastavljaju s dokazivanjem nepravednosti odredaba, pa onda i neodrživosti Pariškoga mirovnog ugovora. Hrvatsko svećenstvo, na čelu s B. Milanovićem, ne sudjeluje u diplomatsko-političkim sporovima nastalim nakon Tripartitne deklaracije. Hrvatsko je svećenstvo smatralo da je u tom pogledu odigralo svoju povijesnu ulogu od 1945. do 1947. i da sada stvar može prepustiti državnom vodstvu. To više što se to vodstvo nakon izopćenja iz komunističkoga tabora našlo $\mathrm{u}$ dosta povoljnom političko-diplomatskom položaju. Pri tome istarsko hrvatsko svećenstvo nakon "krvave krizme" u Lanišću kolovoza 1947., po inerciji se pasiviziralo, duboko razočarano novom vlašću. To razočaranje nije bilo uvjetovano samo položajem $\mathrm{Cr}$ kve i vjerskih sloboda nego općim političkim, gospodarskim i društvenim prilikama. Propadanje sela kao najvitalnijeg i nacionalnog i vjerskog resursa, što je bila posljedica kolektivizacije i megalomanskih planova o industrijalizaciji i elektrifikaciji, crkveni ljudi teško su doživljavali. U nemogućnosti da se aktivno suprotstave spomenutim trendovima, povukli su se $u$ pasivnu rezistenciju.

Iako nije odmah pozdravio Tripartitnu deklaraciju kao poželjan put u rješavanju Tršćanske krize, biskup Santin se na samom početku 1950., u široj elaboraciji problema STT-a dotakao i spomenute Deklaracije. Smatra da obećanje Amerike, Engleske i Francuske o povratku STT-a Italiji treba jednom i realizirati. Prema Santinu, stvar je u rukama Amerikanaca. Zahvaljujući njihovoj materijalnoj i moralnoj pomoći Tito se uspio 
DRUŠ. ISTRAŽ. ZAGREB GOD. 21 (2012) BR. 2 (116)

STR. 485-504

TROGRLIĆ, S.: ISTARSKO HRVATSKO.. othrvati pritiscima i prijetnjama Staljina. Sad je na Amerikancima da izvrše pritisak na jugoslavensko vodstvo da ono u skladu s načelima pravde riješi pitanje STT-a. A za tršćanskog biskupa jedino rješenje je "nanovo ustupiti Italiji STT uz precizne garancije za slavenske narode, ili upravu u zoni "B" povjeriti Anglo-američkoj komandi s tim da Jugoslavija treba na drugo područje premjestiti svoje vojne postrojbe.". Pa iako su Amerikanci do tada uspjeli odvratiti ruski napad na Jugoslaviju, to ne znači, smatra biskup, da će to uspjeti i u nekoj drugoj prilici. Takav pak razvoj situacije značio bi dolazak Rusa u zonu "B" i kraj svih nada da će se riješiti pitanje STT-a. Biskupu je neshvatljivo da Amerikanci jamče obranu u slučaju agresije komunističkom režimu u Beogradu, a to isto ne žele učiniti sa slobodom i imovinom stanovništva u zoni "B", koja - to će Santin u više navrata ponoviti - i nije jugoslavenska (Galimberti, 1996. 367-368).

Paralelno s diplomatsko-političkom borbom odvijala se i promidžbena borba preko medija. I talijanska i jugoslavenska strana služeći se teškim riječima nastojala je pokazati opravdanost svojih zahtjeva. Obje strane bile su svjesne da će njihovi maksimalistički zahtjevi - pripajanje STT-a Italiji, odnosno Jugoslaviji - teško proći. Isto tako postajalo je sve očitije da je oživljavanje STT-a kao posebne državice, u uvjetima suprotnih interesa i podjele na dvije zone, nerealno očekivati. Zato se kao realno rješenje sve više nametalo sankcioniranje postojećeg stanja: Trst i zonu "A" pripojiti Italiji, a zonu "B" dodijeliti Jugoslaviji.

Susreti na razini ministara vanjskih poslova (Sforza - Iveković) u veljači 1950. nisu donijeli nikakav pomak. Sforza je glatko odbio Ivekovićev prijedlog da osnova za pregovore bude dogovor Tito - Togliatti iz 1946., u kojem je Togliatti iznio prijedlog da Italiji pripadne Trst, a za uzvrat Italija će dopustiti ispravke jugoslavensko-talijanske granice u korist Jugoslavije, posebno na području Gorice (Valdevit, 1986., 225-226). Jugoslavenski ministar vanjskih poslova optužio je Italiju da želi stvoriti ozračje prijetnje i pritiska. Na susretu s engleskim predsjednikom vlade u travnju 1951. ministar Sforza izrazio je strah u pogledu postizanja prijateljskoga sporazuma s Jugoslavijom u odnosu na STT. Na početku 1952. Tito je izrazio sklonost prema formiranju STT-a s guvernerom naizmjence Talijanom i Jugoslavenom i viceguvernerom pripadnikom neke druge nacije. Predsjednik talijanske vlade De Gasperi smatrao je da bi Titov prijedlog doveo do pogoršanja odnosa između dviju nacionalnih zajednica i da bi stalno podržavao napetosti između dviju susjednih zemalja (De Castro, 1981.b, 316).

Na četvrtoj godišnjici Tripartitne deklaracije (20. ožujka 1952.) u Trstu je u Kazalištu Verdi (Teatro Verdi) održan skup koji je za svrhu imao podsjetiti saveznike na obveze iz Tripar- 
DRUŠ. ISTRAŽ. ZAGREB GOD. 21 (2012), BR. 2 (116),

STR. $485-504$

TROGRLIĆ, S.: ISTARSKO HRVATSKO... titne deklaracije. Kad je skup u kazalištu završio, sudionici skupa uputili su se na Trg ujedinjenja, gdje je "Lega nazionale" trebala održati koncert. Manifestacija za pridruživanje Trsta Italiji izazvala je reakciju. Saveznička je policija, u sprečavanju okupljanja na Trgu, nastupila dosta brutalno. Došlo je do sukoba, u kojima je bilo mrtvih i ranjenih. Nakon ovih događaja u Trstu se ne samo na političkim skupovima nego i u crkvama s propovjedaonica sve učestalije čuo zahtjev za pripajanje čitavoga teritorija STT-a Italiji.

Članovi "Društva sv. Ćirila i Metoda u Pazinu", istarskoga staleškog svećeničkog društva, na sastanku održanom 18. travnja 1952. donijeli su "Rezoluciju" u kojoj osuđuju talijanski imperijalizam "za Trstom i ostalim našim krajevima uz istočnu obalu Jadranskog mora, gdje je, usprkos tuđinskih infiltracija i sistematskog nepravednog odnarođivanja, ostao naš narod posvuda kompaktno naseljen i u ogromnoj većini te ne će da se vrati opet onamo gdje je već dosta pretrpio i gdje bi ga čekala narodna smrt". Zato istarsko svećenstvo "u duhu katoličkih načela i naravnog prava, vjerno svojoj tradiciji i svome dosadašnjem radu, osuđuje nepravedno posezanje za Slobodnim Teritorijem Trsta i ostalim našim krajevima, kao što i kršenje mirovnog ugovora, te spremno podupire borbu svega jugoslavenskog pučanstva za pravedno rješenje". 18

Rezolucija je bila potvrda neupitnog opredjeljenja istarskoga hrvatskog svećenstva za novu Jugoslaviju. To opredjeljenje nije dovedeno $\mathrm{u}$ pitanje ni onda kad je postajalo sve očiglednije da vlast pomalo zaboravlja sve ono što je Crkva učinila u podršci toj vlasti. Rezolucija slijedi ranija razmišljanja istarskoga svećenstva o prirodnom pravu Hrvata na Istru, jer Hrvati čine većinu istarske populacije. S obzirom na karakter Rezolucije kao dokumenta, nije se spominjalo niti elaboriralo povijesno pravo Hrvata na Istru. U konkretnoj situaciji veću snagu imalo je isticanje povijesnoga prava.

\section{ODNOS PREMA TRŠĆANSKOJ KRIZI OD SREDINE 1952. DO LONDONSKOG MEMORANDUMA 1954.}

Sporazum između SAD-a, Engleske i Italije, potpisan u Londonu 9. svibnja 1952., otvorio je nove napetosti u jugoslavensko-talijanskim odnosima. Pod pritiskom talijanske javnosti, Englezi i Amerikanci su prihvatili da i talijanska strana preuzme neke poslove u upravljanju Trstom. Premda je vojni zapovjednik zone zadržao vrhovnu vlast i premda su, da bi se otklonile jugoslavenske kritike, istaknuta prava i mjere zaštite nacionalnih prava slovenske manjine, $\mathrm{u}$ Jugoslaviji je sporazum protumačen kao jednostrano pripojenje zone "A" Italiji (Pettaco, 2003., 204). Kao odgovor uslijedile su pojačane policijske mjere u zoni "B" kao i uvođenje jugoslavenskih zakona 
DRUŠ. ISTRAŽ. ZAGREB GOD. 21 (2012) BR. 2 (116)

STR. 485-504

TROGRLIĆ, S.: ISTARSKO HRVATSKO.. i odredaba u tu zonu, uz istodobnu suspenziju više od trideset dotadašnjih odredaba.

Odlučniji nastupi i s talijanske i s jugoslavenske strane $\mathrm{u}$ kolovozu 1953. bili su nagovještaj konačnoga rješenja, koje će se ostvariti potpisivanjem Londonskoga memoranduma 5. listopada 1954. Započelo je notom novinske agencije "Jugopress", u kojoj se iznosi mišljenje nekih istaknutih jugoslavenskih političara "o potrebi da se ponovno i to ozbiljno uzme u razmatranje jugoslavenski stav o tršćanskom pitanju nasuprot nepromijenjenom negativnom talijanskom stavu" (Valdevit, 1986., 258). Giuseppe Pella, koji je nakon pada Gasperijeve vlade imenovan premijerom manjinske vlade, notu "Jugopressa" protumačio je kao potvrdu jugoslavenske nakane da nastavi s pripajanjem zone "B". U slučaju takva razvoja događaja Pella je izjavio da će talijanske trupe ući u zonu "A". Tako se Pella, "mirni komercijalist iz Bielle", stjecajem povijesnih okolnosti pretvorio u jastreba talijanske politike (Petacco, 2003., 205).

$\mathrm{Na}$ Pelline izjave Tito je odgovorio sazivanjem velikoga narodnog zbora 6. rujna 1953. u Okroglici (San Basso), udaljenoj samo $6 \mathrm{~km}$ od talijanske granice. Pred 250000 bivših hrvatskih i slovenskih partizana i građana, koji su za tu priliku doputovali specijalnim vlakovima, Tito je u dosta oštrom tonu upozorio susjednu Italiju da bi joj bilo bolje da jedinice koje je počela gomilati prema zoni "A" vrati u vojarne jer od okupacije zone "A" neće biti ništa. Uz ostalo, Tito je rekao: "Moram reći svima da je tršćansko pitanje dospjelo u slijepu ulicu. Prihvaćajući potrebu rješavanja ovog problema, vjerujem da bi jedino rješenje bilo učiniti Trst internacionalnim gradom, a zaleđe Trsta pripojiti Jugoslaviji". Spominjući zonu "B", naglasio je da nema nikakve namjere zagospodariti tim područjem jer se radi o jugoslavenskom teritoriju. ${ }^{19}$ Uslijedila je službena talijanska nota upućena vladama Francuske, Engleske i SAD-a, u kojoj se Tita optužuje zbog megalomanije, jer za njega je jedini izlaz iz krize jednostavno pripajanje cijeloga STT-a Jugoslaviji. Za talijanske krugove to se činilo toliko nerealnim da su postavljali "pitanje koje su prave namjere jugoslavenskog diktatora" (De Castro, 1981.a, 567).

U trenucima kad je zveket oružja na obje strane postajao sve glasniji i kad je Pella u govoru na Kapitolu 13. rujna 1953., svojevrsnom odgovoru na Titov govor u Okroglici, istaknuo talijanske zahtjeve nad cijelim teritorijem STT-a, ponavljajući stari zahtjev za plebiscitom, postalo je jasno da je rješavanje tršćanskoga pitanja dospjelo u slijepu ulicu. Pa kolikogod je talijansko-jugoslavenski vojni sukob više bio teoretska nego stvarna mogućnost zbog nazočnosti 10000 savezničkih vojnika u Trstu, pomicanje jedinica s obje strane granice stvaralo je užas ratne psihoze (Petacco, 2003., 206). Ne želeći da stvari iziđu iz diplomatskih okvira, SAD i V. Britanija su 8. listopada. 1953. 
DRUŠ. ISTRAŽ. ZAGREB GOD. 21 (2012), BR. 2 (116)

STR. $485-504$

TROGRLIĆ, S.: ISTARSKO HRVATSKO.. intervenirale $\mathrm{u}$ tršćansko pitanje. U povijesti je ova intervencija poznata kao Bipartitna deklaracija. Ona nije pretendirala na konačno rješenje, nego je imala za cilj zaustaviti visoke tenzije između talijanske i jugoslavenske diplomacije i prerastanje diplomatsko-političkog spora u oružanu intervenciju. Naime, Bipartitnom deklaracijom je odlučeno, "vodeći računa o pretežno talijanskom karakteru zone "A", da se ova zona ponovno stavi pod talijansku vlast" (De Castro, 1981.a, 585).

Deklaracija je dovela do novih, još većih napetosti u jugoslavensko-talijanskim odnosima. Pella je, izražavajući mišljenje talijanske političke javnosti, smatrao da i eventualno prihvaćanje Bipartitne deklaracije nipošto ne znači da se Italija odriče prava i pretenzija i na zonu "B". Na ovu izjavu Tito je zaprijetio da će u slučaju ulaska talijanskih jedinica u Trst Jugoslavija vojno intervenirati. Obratio se i OUN-u i tako spriječio provođenje Bipartitne deklaracije. U studenom 1953. u Trstu ponovno izbijaju neredi, dolazi do sukoba između demonstranata $i$ agenata javne sigurnosti: 5 . studenog policija puca $u$ nenaoružanu gomilu ispred crkve Sant' Antonio Nuovo, među koju su se sklonili i neki mladići za kojima su tragale policijske snage. U toj pucnjavi dvojica demonstranata su ubijena, a pedesetak ih je ranjeno. Sukobi se nastavljaju i sutradan. Policija ponovno puca po demonstrantima. Ovaj put četvorica su smrtno stradala, a kao i prethodnog dana, pedesetak je bilo ranjenih (Pettaco, 2003., 208). Pogrebne obrede za šestoricu žrtava demonstracija predvodio je tršćanski biskup Antonio Santin. U homiliji izrečenoj tom prigodom, koju je prenosio Radio-Trst, Santin je pozvao na toleranciju i smirivanje situacije (Botteri, 1992., 61).

Lokalne vlasti zamjerile su Milanoviću što na skupu podrške stavovima jugoslavenskoga političkog vodstva u rješavanju tršćanske krize, održanom u Narodnom domu u Pazinu 13. listopada 1953., nije održao govor, iako je sa sjemeništarcima bio na skupu. Sam Milanović dobro izražava svoju poziciju, ali i poziciju Katoličke crkve u Istri u tim trenucima: " (...) ali se nisam usudio javno govoriti, zbog toga što nisam znao da li to žele osobe koje su organizirale miting" (Milanović, 1976., 191). Neugodnosti je Milanović doživio i prilikom nove manifestacije za Trst, održane u Pazinu 15. listopada 1953. Dok se spremao sa sjemeništarcima od V. do VIII. razreda krenuti prema Narodnom domu u Pazinu, gdje se trebao održati skup, povorka koja se kretala prema Narodnom domu kad je primijetila sjemeništarce zaustavila se pred zgradom sjemeništa. Jedan od sudionika povorke, đak pazinske državne gimnazije, popeo se na stubište sjemeništa i počeo govoriti protiv sjemeništa i Crkve. Osjetivši da bi govornik sudionike povorke mogao pozvati da provale u sjemenište, Milanović je istupio pred demonstrante i počeo govoriti o zaslugama istarsko- 
DRUŠ. ISTRAŽ. ZAGREB GOD. 21 (2012) BR. 2 (116)

STR. $485-504$

TROGRLIĆ, S.: ISTARSKO HRVATSKO.. ga svećenstva u borbi za narodna prava te njihovoj spremnosti da to učine i sada. Na te je riječi netko iz mase uzviknuo: "A ako Vam zabrani biskup?", na što je Milanović manirom iskusna diplomata odgovorio: "Onda ga ne bismo poslušali". Umjesto negodovanja, uslijedio je pljesak i poziv sjemeništarcima da se priključe ostalima u Narodnom domu (Milanović, 1976., 191-192).

Među govornicima u Narodnom domu ovaj put je bio i Milanović. Kao i toliko puta ranije, da bi opravdao jugoslavenske zahtjeve prema Trstu, ali i cjelokupnom STT-u, upotrijebio je povijesne argumente. Povratak u prošlost trebao je pokazati kako je na jugoslavenskoj strani, osim prirodnog (etničkog) prava, i ono povijesno. Međutim, zbog isticanja uloge svećenika u nacionalnoj borbi istarskih Hrvata, govor su neki članovi hrvatske vlade okvalificirali kao previše "klerikalan". Milanović je ponovno preko Ritiga morao opravdavati svoje stavove i dokazivati da njegov govor nije imao klerikalni naboj (Milanović, 1976., 192).

Na pasivnost istarskoga svećenstva u ovim događajima, o kojoj se na mjerodavnim političkim mjestima govorilo, upozorio je B. Milanovića uime Komisije za vjerske poslove njezin tajnik Milan Pallua: "Mislim da se to (prevelika pasivnost, op. aut.) desilo iz akcidentalnih, a ne esencijalnih razloga, ali to je šteta, jer je to bila prilika u kojem je rodoljublje istarskog klera moglo dati sebi puni zamah, koji sigurno ne bi bio ništa drugo no spontan. Jedino mi skromnost i, oprostite, možda nespretnost pojedinaca može protumačiti te činjenice, jer znadem i suviše dobro rodoljubni puls istarskog klera (...) $\mathrm{Ne}$ treba pridavati nikome, a napose širim slojevima predobro pamćenje prošlih zasluga, nego ih treba svakom prigodom osvježavati". $20 \mathrm{O}$ razlozima političke pasivizacije istarskoga svećenstva već je bilo nešto rečeno. Mislim da je ovdje važno uočiti neke stvari. Vlast je registrirala "političku pasivizaciju" istarskoga klera kao negativnu pojavu, uz izričitu preporuku da se iziđe iz toga stanja. Prošlim zaslugama ne može se prekriti sadašnja pasivnost, jer u politici se uvijek treba dokazivati.

Palluino upozorenje djeluje utoliko čudnije što je Odbor Društva svećenika sv. Cirila i Metoda "u ime svoje i svojih članova" 17. listopada 1953. donio "Izjavu" koja na neki način sintetizira stav istarskoga svećenstva o tršćanskoj krizi. Odmjerena i uravnotežena, bez političkih animoziteta i optužbi, ona zorno svjedoči o nacionalnom opredjeljenju istarskoga svećenstva. Zato je donosimo u cijelosti.

"U skladu s već poznatom tradicijom i dosadašnjim rezolucijama protestiramo protiv posezanja Italije za Istrom i ostalim našim hrvatskim i slovenskim primorskim krajevima, te izjavljujemo, da osim zone "B" također zona "A" sa Trstom mora biti priključena Jugoslaviji i to iz već znanih geografskih, 
DRUŠ. ISTRAŽ. ZAGREB GOD. 21 (2012), BR. 2 (116)

STR. $485-504$

TROGRLIĆ, S.: ISTARSKO HRVATSKO.. ekonomskih i etničkih razloga. Granica uz pojas koji bi bio zasječen $u$ jugoslavensko narodno tijelo te bi odsjekao naše zaleđe od mora, ostala bi uvijek neprirodna i nepravedna. $\mathrm{Hr}$ vati i Slovenci, koji također u zoni "A" sižu kompaktno nastanjeni sve do mora i preko predgrađa do središta samog Trsta, imaju prirodno pravo da bude to more također njihova nacionalna državna granica. To zahtijevaju također ekonomski razlozi, po kojima Trst nije potreban Italiji već zaleđu, kojemu i onako pripada geografski. Hrvatsko i istarsko svećenstvo, kao što uvijek do sada, ostaje i nadalje solidarno sa svojim narodom u borbi za njegova prava i njegovu slobodu".21

U listopadu 1953. grupu inženjera koja je prisustvovala kongresu u Rimu primio je $\mathrm{u}$ audijenciju papa Pio XII. U audijenciji se našao i tršćanski gradonačelnik, Gianni Bartoli, po struci inženjer politehnike. Jugoslavenski je tisak ovu audijenciju popratio dezinformacijom da je papa u posebnu audijenciju primio Bartolija i da mu je tom prilikom rekao kako će nakon Tršćana biti oslobođeni i Istrani. Sve je to učinjeno s jasnom namjerom da se lakše napadne papa, u skladu s jednim od uzvika na mitinzima: "Dolje papa i njegova klapa". Radio-Vatikan je demantirao ovu dezinformaciju, uz napomenu kako se papa nije posebno sastao s Bartolijem niti je s njim govorio o političkim pitanjima. 22 Vlada je znala da u pogledu tršćanske krize jugoslavenski biskupi dijele njezine stavove, međutim iz prepoznatljivih političko-propagandnih razloga trebalo je napade na biskupe, zbog stava prema svećeničkim udruženjima, povezati s njihovim pokoravanjem vatikanskoj imperijalističkoj politici. 23

Memorandum o suglasnosti između vlada Italije, Ujedinjenoga Kraljevstava, Sjedinjenih Američkih Država i Jugoslavije o Slobodnom Teritoriju Trsta, potpisan 5. listopada 1954. godine, označio je kraj desetogodišnje tršćanske krize. Dugi i mučni pregovori predstavnika SAD-a i V. Britanije s Vladimirom Velebitom, jugoslavenskim ambasadorom u Londonu, od veljače do svibnja 1954., doveli su do usaglašavanja stavova da polazište $u$ rješavanju krize treba biti prihvaćanje situacije stvorene okupacijom zone "A" od strane Anglo-Amerikanaca i zone "B" od strane Jugoslavije (Puppo, 1987., 18). Kasnije usuglašeni stavovi triju zemalja, koje su vojno zauzele STT, o povlačenju vojnih snaga iz obiju zona i uspostavljanje talijanske civilne uprave $\mathrm{u}$ zoni "A" $\mathrm{i}$ jugoslavenske $\mathrm{u}$ zoni "B" prihvatila je i talijanska diplomacija, pa je na Memorandum svoj potpis stavio i talijanski ambasador Manlio Brosio.

Kad su nakon potpisivanja Memoranduma talijanske jedinice ušle u zonu "A" i u grad Trst, među stanovnicima Trsta zavladalo je oduševljenje. Zanos oduševljenja ipak je bio pomiješan s razočaranjem s obzirom na stanje u zoni "B", o čemu je Santin razgovarao s talijanskim predsjednikom Luigijem 
DRUŠ. ISTRAŽ. ZAGREB GOD. 21 (2012) BR. 2 (116)

STR. $485-504$

TROGRLIĆ, S.: ISTARSKO HRVATSKO...

\section{ZAKLJUČAK}

Einaudijem prigodom njegova posjeta Trstu i dolaska na liturgijsko slavlje u katedrali sv. Justa, a u povodu povratka Trsta "majci domovini" (Santin, 1978., 193-194).

Već 13. listopada 1954. Konzistorijalna kongregacija obavijestila je biskupa Nežića kao administratora hrvatskoga dijela Pazinske apostolske administrature da, čim stupi na snagu Londonski memorandum, može preuzeti crkvenu upravu u hrvatskom dijelu nekadašnje zone "B" (Nežić, 1988., 16). Zadovoljstvo zbog rješenja tršćanske krize i dobivanja 12 župa i 6 kapelanija bilo je pomućeno zbog sve jače represije državnog aparata prema Katoličkoj crkvi u Hrvatskoj, od čega nije bila izuzeta ni Crkva u Istri. Možda je to glavni razlog što s crkvene strane nije bilo javnih manifestacija podrške novom uspjehu jugoslavenske diplomacije.

Aktivno uključivanje najvećega dijela hrvatskoga svećenstva $\mathrm{u}$ Istri u diplomatsku borbu za sjedinjenje Istre s maticom Hrvatskom bilo je posljedica spoznaje da bi ostanak Istre u Italiji značio kraj hrvatske prisutnosti u ovom najzapadnijem dijelu hrvatskoga etničkog prostora. Stavljajući općenarodne interese ispred onih staleških, ali i usko ideoloških, nisu se libili pružiti podršku novoj, komunističkoj, vlasti, jer su u njoj vidjeli jedinu realnu snagu sposobnu da ostvari vjekovni san istarskih Hrvata o sjedinjenju sa sunarodnjacima preko Učke.

Pokretač svih akcija među svećenicima bio je Božo Milanović, svećenik Tršćansko-koparske biskupije. Autoritetom intelektualca i dosljednoga borca za hrvatska nacionalna prava u Istri, još od vremena austrijske vlasti, uspio je hrvatsko svećenstvo u Istri pridobiti za svoju političku orijentaciju podržati novu, "narodnu vlast", posebno u njezinim nastojanjima u diplomatsko-političkoj borbi za sjedinjenje Istre s maticom Hrvatskom. Ta podrška posebno je došla do izražaja u prvoj fazi diplomatske borbe za Istru (1945.-1947.), kada se svećenici, preko svojega staleškog udruženja "Zbora svećenika sv. Pavla za Istru", izravno uključuju u tu borbu. U talijanskoj javnosti taj rad hrvatskoga svećenstva okvalificiran je kao krajnje iredentistički, dok je Milanović nazivan prvakom hrvatske klerikalne organizacije.

Potpisivanjem Mirovnog ugovora u Parizu 10. veljače 1947. između Italije i sila pobjednica, prema kojem je čitava Istra, osim Bujštine i Koparštine, pripala Jugoslaviji, završila je prva, i ujedno najdinamičnija, faza borbe za Istru. Hrvatsko je svećenstvo smatralo da je na diplomatsko-političkom planu odigralo svoju povijesnu ulogu te da svaku daljnju aktivnost na planu diplomatske borbe treba prepustiti državnim tijelima. Nakon ratifikacije Pariškoga mirovnog ugovora i uspostavljanjem jugoslavenskoga zakonodavstva na pridruženom 
DRUŠ. ISTRAŽ. ZAGREB GOD. 21 (2012), BR. 2 (116)

STR. $485-504$

TROGRLIĆ, S.: ISTARSKO HRVATSKO... području Istre, država se osjećala sigurnom, pa joj svećenici kao suputnici i suradnici nisu više trebali. Osim toga, unutar hrvatskoga svećenstva, pod utjecajem pojačane represije, a posebno nakon ubojstva svećenika Miroslava Bulešića, došlo je do određene samoizolacije u odnosu na raniju "bianco" podršku svim državnim mjerama.

Ipak, vjerno svojem nacionalnom opredjeljenju, gradeći političke stavove na Milanovićevoj mudrosti i pragmatizmu da režimi prolaze, a narod ostaje - istarsko hrvatsko svećenstvo i u sljedećem razdoblju promptno je reagiralo na svaki iredentistički pokušaj svojatanja Istre, posebno u vrijeme tršćanske krize (1952.-1954.), ističući njezin dominantno hrvatski karakter.

\section{BILJEŠKE}

1 Julijska Venecija (tal. Venezia Giulia, slov. Julijska krajina) naziv za povijesnu regiju koja je obuhvaćala Trst, Goricu, Gradišku, dio Notranjske Kranjske, Kanalsku dolinu, Istru i od 1924. godine Rijeku, tj. područje koje je poslije Prvoga svjetskog rata pripalo Italiji (Cecotti, 2005., 359; Dota, 2010., 7).

2 Glas Istre, br. 22-23, 8. siječnja 1944., 2.

3 Spomenutim sporazumima potpisanim u lipnju Anglo-Amerikanci su prinudili jugoslavensku vladu da povuče vojsku iz Trsta, Monfalconea (Tržiča), Gorice i Pule s užom okolicom. Od toga dijela formirana je zona "A" pod anglo-američkom vojnom upravom. Ostali dio Istre kao zona "B" stavljen je pod Vojnu upravu Jugoslavenske armije (VUJA) (Milanović, 1996., 134).

4 Hrvatsko svećenstvo moći će osnovati svoje staleško udruženje, NOP će pomoći pokretanje vjerskoga lista na hrvatskom, kao i povratak zgrade "Đačkog doma" za potrebe hrvatskoga sjemeništa. "Društvu sv. Mohora za Istru" omogućit će se osnivanje podružnice u Pazinu radi širenja vjerske i druge literature. Molitvenici, katekizmi i druge vrste vjerskih knjiga mogu se širiti nesmetano. Do konačnog uređenja državnih granica bogoslovi i sjemeništarci neće se zvati u vojnu službu. Na kraju se jamči nesmetan povratak svećeniku Zvonimiru Brumniću u Istru. Arhiv Istarskoga književnog društva Juraj Dobrila u Pazinu (dalje: AH IKD), Osobni fond Bože Milanovića, dalje: (OF BM), Sporazum od 16. srpnja 1945.

5 Iako se ne navodi tko je trebao obavijestiti biskupe, iz konteksta proizlazi da je to trebao učiniti sazivač, tj. JNOF za Istru.

${ }^{6}$ AH IKD, OF BM, Memorandum savezničkoj komandi u Trstu, 20. srpnja 1945.

7 Na području Tršćansko-koparske biskupije bila je 71 hrvatsko-slovenska župa i samostalna kapelanija, 14 je bilo talijanskih, a 9 mješovitih (u mješovite su se računale one u kojima je bilo više od $10 \%$ pripadnika drugoga naroda), u Porečko-pulskoj biskupiji bile su 42 hrvatske župe, 7 talijanskih i 11 mješovitih, dok je u Riječkoj biskupiji bilo 19 hrvatskih župa i 3 talijanske. To znači da su u sve tri biskupije bile 132 hrvatsko-slovenske župe ili 75\%, 21 je bila talijanska ili $12 \%$, a 23 su bile mješovite ili $13 \%$. AH IKD, o. a. BM, Popis samostalnih župa i kapelanija u Istri. 
DRUŠ. ISTRAŽ. ZAGREB GOD. 21 (2012) BR. 2 (116),

STR. $485-504$

TROGRLIĆ, S.: ISTARSKO HRVATSKO..
${ }^{8}$ Lettera di S. E. Il Vescovo alla citta' di Pola, bez datuma. U: L'Arena di Pola, br. 72, Pula, 24. ožujka 1946., 1.

${ }^{9}$ AH IKD, OF BM, Spomenica Zbora svećenika sv. Pavla za Istru Savezničkoj komisiji za razgraničenje Julijske krajine, Pazin, 12. veljače 1946.

10 U svojoj doktorskoj disertaciji obranjenoj na bečkom "Augustineumu" 1918. Milanović je, na temelju filozofije Tome Akvinskoga, dokazivao moralnu opravdanost revolucija radi promjene vlasti (Milanović, 1976., 26).

11 Gore srca, br. 17, Rijeka, 1. prosinca 1946., 1.

12 Gore srca, br. 18, Rijeka, 15. prosinca 1946., 1.

13 AH IKD, OF BM, kut: Crkva u Istri, fasc: b.o, Sažetak predavanja Leopolda Jurce na slovenskom: "Zakaj smo slovenski in hrvaški duhovniki po zadnji vojni hoteli ostati u novoj Jugoslaviji?"

$14 \mathrm{Ni}$ talijanska delegacija nije bila sklona plebiscitu, jer se bojala da bi glasovanje talijanskih komunista za Jugoslaviju mogao biti jezičac na vagi u korist Jugoslaviji. Isto tako plašili su se da bi pritisci jugoslavenskog režima za vrijeme plebiscita imali negativne posljedice za talijansku stvar. Plebiscitu su bili skloni jedino Julijski komitet i biskupi Santin i Radossi. Iako svjesni slavenske većine, računali su da bi Slaveni nekomunisti, zbog represivnoga držanja režima prema neistomišljenicima, mogli glasovati uza ostanak Istre u Italiji (Petacco, 2003., 155).

15 AH IKD, OF BM, fasc: M2A170, Telegram maršalu Titu, Pazin, 25. veljače 1947.

${ }^{16}$ AH IKD, OF BM, fasc: M2A170, Telegram ministru predsjedniku Vladimiru Bakariću, Pazin, 25. veljače 1947.

17 U osobnoj ostavštini B. Milanovića, kao ni u njegovim autobiografskim zabilješkama, nigdje se ne spominje Tripartitna deklaracija. Isto tako biskup Santin u svojem detaljnom razmatranju pitanja istočnih talijanskih granica ne spominje tu deklaraciju.

18 AH IKD, OF BM, Rezolucija od 18. travnja 1952.

19 Glas Istre , br. 36, Pula, 12. rujna 1953., 1.

20 AH IKD, OF BM, Pismo Milana Pallue B. Milanoviću, Zagreb, 31. listopada 1953.

21 AH IKD, OF BM, Izjava od 17. listopada 1953.

22 AH IKD, OF BM, Pismo biskupa Josipa Pavlišića Boži Milanoviću, Rijeka, 19. listopada 1953.

23 AH IKD, OF BM, Pismo biskupa Pavlišića B. Milanoviću, Rijeka, 22. rujna 1953.

\title{
IZVORI I LITERATURA
}

\author{
fond Bože Milanovića. \\ Glas Istre (1944., 1953.), Pula. \\ Gore srca (1946.), Rijeka.

Arhiv Istarskog književnog društva Juraj Dobrila u Pazinu, Osobni 
DRUŠ. ISTRAŽ. ZAGREB GOD. 21 (2012), BR. 2 (116),

STR. $485-504$

TROGRLIĆ, S.: ISTARSKO HRVATSKO..
Botteri, G. (1992.), Antonio Santin, Pordenone, Edizioni Studio Tesi.

Bratulić, J. (2005.), Pregelj Ivan, Istarska enciklopedija, Zagreb, Leksikografski zavod Miroslav Krleža.

Cecotti, F. (2005.), Julijska Venecija, Istarska enciklopedija, Zagreb, Leksikografski zavod Miroslav Krleža.

De Castro, D. (1981.a), La questione di Trieste, l'azione politica e diplomatica Italiana dal 1943. al 1954, vol. I, Trst, Edizoni Lint.

De Castro, D. (1981.b), La questione di Trieste, l'azione politica e diplomatica Italiana dal 1943. al 1954, vol. II, Trst, Edizioni Lint.

Dota, F. (2010.), Zaraćeno poraće, Zagreb, Srednja Europa.

Galimberti, S. (1996.), Testimonianze dall' archivio privato, Trst, Mgs Press.

Gomiero, A. S. (1995.), Nelle arene di Nerone. Diario di galera, Milano, CENS.

Grah, I. (1992.), Ivan Pavić oporbenjak fašizmu i komunizmu, Istarska Danica, Pazin, IKD Juraj Dobrila.

Grah, I. (1997.), Crkvene i političke promjene u Istri 1945.-1947. Dometi, 7-12: 57-70.

Grah, I. (2004.), Istarski narodnjaci (4), Ladonja, vjerski kulturno-informativni list, br. 6, Pazin, str. 19.

Hrženjak, J. (ur.) (1952.), Istra i Slovensko primorje, borba za slobodu kroz vjekove, Beograd, Rad.

Istranin, N. (pseudonim) (1965.), Salmi di galera, Vicenza, ESCA.

Milanović, B. (1976.), Moje uspomene, Pazin, IKD sv. Ćirila i Metoda.

Milanović, B. (1996.), Istra u 20. stoljeću, knjiga 2., Pazin, Josip Turčinović.

Nežić, D. (1988.), Od Apostolske administrature u Pazinu do jedinstvene biskupije и Рогес̌u 1947 - 1978, Pazin, IKD Juraj Dobrila.

Petacco, A. (2003.), Egzodus, Zagreb, Durieux.

Puppo, R. (1987.), Alle radici del Memorandum-Londra 1954., Contributi per la storia contemporanea della Venezia Giulia, Quaderni Istriani 1 (Fulvio Salimbeni, gl. ur.), Trst, Edizioni Triestepress.

Riccardi, A. (1989.), Lettere inedite di mons. Radossi e mons. Santin sul problema giuliano 1946., Contributi per la storia contemporanea della Venezia Giulia, Quaderni Istriani 2 (Fulvio Salimbeni, ur.), Trst, Edizioni Triestepress.

Santin, A. (1978.), Al tramonto, ricordi autobiografici, Trst, LINT.

Valdevit, G. (1986.), La questione di Trieste 1945 -1954., Milano, Franco Angeli. 
DRUŠ. ISTRAŽ. ZAGREB GOD. 21 (2012), BR. 2 (116),

STR. $485-504$

TROGRLIĆ, S.: ISTARSKO HRVATSKO.

\section{Istrian Croatian Clergy and the Diplomatic-Political Struggle for the Union of Istria with Croatia (1945-1954)}

Stipan TROGRLIĆ

Institute of Social Sciences Ivo Pilar - Regional Centre Pula, Pula

This research paper, based on the archival materials, press and literature, analyzes the role of the Istrian Croatian clergy in the diplomatic-political struggle for the union of Istria with its homeland Croatia, in the first decade of that struggle after World War II. In the first phase (1945-1947) the Croatian clergy, led by charismatic Božo Milanović, on the invitation of the new "national government" joins actively in that struggle: enters the negotiating teams, writes development plans for politicians, delivers the Memorial to the Allied Commission in Pazin, holds speeches on political meetings. In the second, longer phase (1947-1954) the Croatian clergy is (self)marginalised in the diplomatic-political events concerning the solution for the disputable area between Yugoslavia and Italy, known as the Free Territory of Trieste. On the one hand, it was the consequence of the conviction of the government that it no longer needed the help of the clergy, and on the other, the clergy itself considered it had played its historical role in the previous phase and that the established state can manage the new challenges of the diplomatic-political struggle for "the rest" of Istria by itself. The work of the clergy was now reduced to writing memorials and statements in which it rises against the Italian irredentistic demands for Istria and providing support to Yugoslav government in the defence of the western borders.

Keywords: Istria, diplomatic struggle, union, Croatian clergy, Božo Milanović 